DOI: 10.15643/libartrus-2015.1.3

\title{
Britain Social Novel at the End of the 20th Century
}

\author{
(C) V. G. Novikova \\ Lobachevsky National Research University of Nizhni Novgorod \\ 23 Gagarin Ave., 603950 Nizhni Novgorod, Russia. \\ Email:wnovikova@mail.ru
}

\begin{abstract}
The purpose of this paper is to reveal the peculiarities of the social novel genre content, the traditions of which are rooted in the modern era and transformations under the influence of radical changes in the type of thinking in the postmodern outlook. Postmodern fictional way of thinking is based on the image of the world as a combination of multiplying realities. As the result, the social reality started being perceived as a construction in which complicated-by-intelligence values disappear while elementary routine constructions multiply. Epistemological uncertainty also influenced this result. In conditions of "trading reality" the intellectuals lose their positions, traditional values destruct, humanities knowledge fades as it doesn't have any certain market cost, the dream about the social equality vanishes together with the idea of socialism itself. Discourse of possession can not be combined with the discourse of moral. New positions are obtained by the representatives of different subcultures that become the centre of amorphous mass. The modern British social novel represents the social changes, which have occurred owing to the changes of the paradigm of thinking. The absence of socially significant landmarks deprives the British of an impulse to socially significant actions, allows manipulations with masses. The absence of national idea is connected with the painful search of the national identity, which is believed to be the main point in modern literary process.
\end{abstract}

Keywords: British social novel, type of thinking, concept of reality, multiplied realities.

The social novel in Great Britain appeared in the epoch of Industrial revolution as a reaction to industrialization, social, political and economic movements. Different sub-genres of the social novel of the X1X century included the industrial novel, "Condition of England" novel, social - problem novel. Special interest to this period is found in the 1980-90- $s$ in the works of E. Ermarth, C. Gallagher, J. M. Guy, N. Armstrong and many others $[9,10,12,2]$.

The genre specifics of a social novel in all its aspects are the product of New Time. Firstly, the issue is connected with the development of the industrial capitalism. Secondly, classical way of thinking makes people search for causal links between a man and society and the rules of social development. It also assumes positive historical movement. The priority of scientific knowledge in dynamics of social development determines a special place of the intellectuals (the so called "people of knowledge") in social life. Two categories of classical novel undergo the most radical changes. These categories are the representation of the interaction between people and society, and the idea of historical progress. The social novel in the English literature of the 20th century till the 70-s finds reflection in the researches of M. Bradbury, S. Connor, A. Gasiorek, A. Sinfield, Ph.Tew in realistic traditional points of view and reflection of social changes in the novel and in new tradition of the "cultural studies" $[4,7,11,20,21]$.

The purpose of this paper is to reveal the peculiarities of the social novel genre content, the traditions of which are rooted in the modern era and transformations under the influence of radical changes in the type of thinking in the postmodern outlook. 
Initial methodological position for the research is the idea of the "type of thinking" defined by the existence of combined scientific, art and ordinary methods.

Classical social novel is founded on the idea of social determinism. It assumes the existence of objective reality. The postmodernist type of thinking is based on understanding the world as a set of multiplied realities [8], multiply ambiguous [1], the world of discourses as ontological landscape [16, 18]. In this case every reality is the product designed and confirmed by daily social interactions. Realism in the novel is "the world in which narrative verities have turned into narrative possibilities" [17]. The social reality is perceived as an imaginary construction. The fundamental opposition of an epoch is based on the fact that the reality depends on creative activity of a person, however the consciousness of today's individual cultivates elements of the ordinary and smoothes to the ordinary level. "Reality" as a reality of not only things, but also ideas, purposes, ideals, knowledge, social institutions do not disappear absolutely, but lose "complicated by intelligence" values, leaving only elementary designs of "daily occurrence". The concept of reality and the potential for its representation are revealed on the material of the novels by M. Bradbury, D. Barns, W. Boyd, T. Lott, B. Elton, D. King.

The British writers create the panorama of a trading civilization of the post - late capitalism during the postmodernism epoch. Self-sufficiency of a person of the classical social novel is replaced by self-construction as it is presented in sociological and psychological researches. An intellectual as a social figure defining public consciousness up to the end of the sixties becomes a simulacrum. At the end of the century he swiftly loses his social positions. In M. Bradbury's "The History Man" the reader finds the reflection of this process. It is especially evident in connection with the profession of the protagonist, engaged in sociology. "People of knowledge" cease to be involved in development of senses in the last decades of the 20th century. Now they apply to the method of deconstruction of the old ideological systems, dividing them into separate components and combining in new systems depending on the demand of the market. The exclusive circle is created. Only those intellectual goods are bought which can be acquired by intellectually backward taste of mass consumer, therefore other goods are not made. In D. Barns's novel "England, England” this tendency thrives to its logic end. False national conceptshere is created. The complex of simulacrum replaces original national cultural values. In Ben Elton's novels the consumer society turns into "a society of shows" which are imitations of real life. They include many things and among them the television programs in aggregate creating daily reality for the mass consumer.

The character, trying to place "realissimus of the consciousness" in the world consisting of a set of realities, defines specificity of the modern social novel. A characteristic example in this plan are W. Boyd's novels. In "Brazzaville Beach" (1990) the position of an early postmodern is reflected. It is the idea of the necessity for variability of a person (protheism), the necessity for radical changes in society. Here the thinking results on social action results become actual. Aspiration of a person to the realized model of behaviour and style of life, the theme of a role, masks find expression in the "Armadillo" (1990). The specificity of a postmodernist situation provoking the modus of theatricality, leads to the situation where the social space becomes "empty". There is no organizing semantic centre, but there is a commodity market which concerns neither ethical nor aesthetic categories.

This objective truth of the 19 th century social realism is also actual in the end of the 20th century. The difference lies in the fact that playing characters fill gaping emptiness with the senses, which create the "self-organized systems", the models of daily occurrence based on humanitarian and natural-science knowledge. 
The "industrial" novel of the given period artly comprehends the attempt to revive the Victorian synthesis of discourses of property and morals undertaken by the government of M. Thatcher. It proves again, that the philosophy of property appears incompatible with traditional morals. The destiny of "the industrial person" during the Thatcherite era receives artistic realization in T.Lott's "Rumours of a Hurricane" (2002). The tradition of the classical social novel is especially strong in this text. The events of the novel began in 1979 and came to the end in 1991 (the years coinciding with the activity of M. Thatcher as the Prime minister, 1979-1990). The protagonist is a bearer of those values which were cultivated by ideology of an industrial society. However the family centre as the optimum model of life does not look here convincing. Socialist idea about the saving social force of strikes is deconstructed too. During the period of Thatcherism a proprietor-businessman, according to new state ideology, should have rescued the national economy. However the philosophy of private property appears incompatible with moral values cultivated by the same ideology. Here it is possible to recollect a familiar expression of this period "Max and Spencer" (the name of a network of cheap department stores) have won Marx and Engels". This victory defines social problematics of novels of the next decade when the epoch of "narrow-minded barbarity" reaches the apogee. Pat Barker's "The Century's Daughter" (1986, republished in 1996 as "Liza's England") depicts urban England in the state near to anarchy, a society littered with condemned houses, disused factories, redundant workers and dysfunctional families. "Thatcherist economics have succeeded in destroying Liza's community more effectively than the two world wars or the depression", - Brannigan wrote [5]. Written in sixteen years after "Daughter of century" Lott's novel convincingly depicts the mechanism of this destruction.

Results of this destruction in "football hooligan literature" are fully represented. It is a new subgenre of the social novel in the end of the 20th century. Numerous articles (see bibliography of S. Redhead) testify to it [19]. In considerable number of such novels the image of a city working suburb man, "the person of crowd" is the central character. In the trilogy of John King "The Football Factory"(1996), "Headhunters"(1997), "England Away"(1998) the image of a football hooligan defines the plot. The majority of chapters represent a stream of consciousness of an inhabitant of the city outskirts. He is the fan of "Chelsea", a member of a big group which is named "mob", almost weekly entering fight with similar groups from other areas. The themes of novels unite round the semantic centre which can be designated as "violence". The variety of its forms: from state to religious-terroristic, family, sexual ones creates a depressing picture of modern society. This picture is supplemented with a kind of destroyed and dirty working suburbs which were the pride of social projects of the 50-60-s.

R. Hoggart in "The Uses of Literacy" (1957) classifies the middle class and aristocracy as "they" and the working class as "we" [13]. King's character says that "we" are the ethnic minority thrown out by the system. Market freedom is to kill or be killed. The weak do not live long in this country. King's novels help to understand the truth of the postindustrial period. The traditional culture essentially becomes secondary, forgotten, subculture. Marginal subcultures move to the centre. Modern culture of industrial period was built as science and education civilization. In the postindustrial world the masses are enslaved by stereotypes, these are those, who will apprehend everything if only it appears entertaining. They do not know and do not wish to know literature and especially its language. They have their own manner of speech, as John King shows in this case. At the same time one can assert with good reason, that it is the same classical social novel as its problems are to give the detailed description of the working class position and to cause compassion to its destiny. Probably the same 
can be done to the destiny of modern civilization as for a considerable quantity of people replacement of the higher senses with substitutes has already occurred.

M. Bradbury declares in the preface to his remarkable book "The Social Context of Modern English Literature": "This book exists in the middle ground between literary study, sociology, and intellectual history, in an area that has come to be called 'cultural studies'. The area requires a word of explanation. Literature does not normally play an important part in the sociological interpretation of society; and, likewise, one of the familiar tenets of modern literary study is that the business of criciticism is not with context but text - the text of this poem, this novel, this play, looked at in and for itself. But literature is a social product, and can properly be studied as such" [4].

Rare example of the reference to the mentioned problem on the material of the last decades of the XX-th century literature is the monograph of C. Hutchinson "Reaganism, Thatcherism and the Social Novel" (2008). Author offers definition of the social novel: "The novel that addressed contemporary social and political concerns more or less explicitly" [14].

However restriction to the research of the novel by frameworks of social problems lacks fundamental investigation. Productive way we find in article of Ch. Bazerman about a genre. "The move of genre into the realm of social fact itself has consequences for our understanding of genre, for it makes possible the invocation of work in psychology, sociology, and anthropology on social, cultural and psychological typification. Moreover, we now enter an interdisciplinary consideration of the interaction between culturally received categories created in social processes and personally salient categories arising in psychological activities... it invites us to see the kinds of texts and cultural objects typically studied alongside the kinds of texts and cultural objects typically studied by other fields in the human sciences. This placement of literature and the other arts within the wide array of culturally produced objects recognizes other texts and objects are of cultural value and makes them available for forms of literary and cultural interpretation (a move already taken by new historicists and other cultural studies analysts). Even more radically, this move opens literary and other cultural objects to the kinds of examination and questioning posed by other fields" [3]. We agree with thought of authors "A Companion to the Philosophy of Literature". The first part of the volume "concerns ways of characterizing and ways of showing, the relations or the complex set of relations that connects philosophy and literature... Here questions arise concerning what literature might show that philosophy (construed one way) can only say" [6]. This way conducts to research philosophy of mind. Such method is found out in works of Ph. Kitcher. Kitcher's contributions to the philosophy of science and his more recent endeavors into the philosophy of literature and of music are grounded in the same big picture attitude towards the human mind - an attitude that he would undoubtedly call 'pragmatic': one that emphasizes the importance of those mental processes that are not (or not entirely) rational. But it investigates the modernist novel [15]. Research of philosophy of mind as the mode of thinking in the modern British novel leads to certain conclusions.

Postmodern fictional way of thinking is based on the image of the world as a combination of multiplying realities. As the result, the social reality started being perceived as a construction in which complicated-by-intelligence values disappear while elementary routine constructions multiply. Epistemological uncertainty also influenced this result. In conditions of "trading reality" the intellectuals lose their positions, traditional values destruct, humanities knowledge fades as it doesn't have any certain market cost, the dream about the social equality vanishes together with the idea of socialism itself. Discourse of possession can not be combined with the discourse of moral. New positions are obtained by the representatives of different subcultures that become the centre of amorphous mass. 
The modern British social novel represents the social changes which have occurred owing to the changes of the paradigm of thinking. The absence of socially significant landmarks deprives the British of an impulse to socially significant actions, allows to manipulate with masses. The absence of national idea is connected with the painful search of the national identity which is believed to be the main point in modern literary process.

\section{REFERENCES}

1. Amy J. Modern Language Quarterly. 2005. Vol. 66. No. 1. P. 148

2. Armstrong N. How Novels Think: The Limits of British Individualism from 1719-1900. Columbia University Press, 2005. P. 191.

3. Bazerman Ch. Journal of The Interdisciplinary Crossroads. 2003. Vol. 1(2). Pp. 123-142.

4. Bradbury M. The social context of modern English literature. Schocken Books, 1971. P. 277.

5. Brannigan J. Orwell to the Present. Literature in England. 1945-2000. Palgrave Macmillan, 2003. P. 256.

6. A Companion to the Philosophy of Literature (Blackwell Companions to Philosophy, Vol. 44). Ed. G. L. Hagberg, W. Jost. Wiley-Blackwell, 2010. P. 568.

7. Connor S. The English Novel in History 1950-1995. Routledge, 1995. P. 272.

8. Ellis J. M. Against Deconstruction. Princeton, 1989. P. 117.

9. Ermarth E. Realism and Consensus in the English Novel: Time, Space and Narrative. Princeton University Press, 1983. P. 294.

10. Gallagher K. The Industrial Reformation of English Fiction: Social Discourse and Narrative Form, 1832-1867. University of Chicago Press, 1985. P. 320.

11. Gasiorek A. Post-war British fiction. Realism and after. A Hodder Arnold Publication, 1995. P. 202.

12. Guy J. M. The Victorian Social-Problem Novel: The Market, the Individual and Communual Life. Palgrave Macmillan, 1996. P. 256.

13. Hoggart R. The Uses of Literacy. Gardners Books, 2009. P. 320.

14. Hutchinson C. Reaganism, Thatcherism and the Social Novel. Palgrave Macmillan, 2008. P. 224.

15. Kitcher Ph. Joyce's Kaleidoscope: An Invitation to Finnegans Wake. Oxford University Press, 2009. P. 332.

16. McHale Br. Postmodernist Fiction. Taylor and Francis, 1987. P. 9-10.

17. Morace R. A. The Dialogic Novels of Malcolm Bradbury and David Lodge. Southern Illinois University Press, 1989. P. 13.

18. Pavel T. Studies of the Twentieth Century Literature. 1982. Vol. 6. No. 1. P. 188-189

19. Redhead S. Entertainment and Sports Law Journal. 2007. URL: www2.warwick.ac.uk/fac/soc/law/elj/eslj/issues/volume5/number2/redhea/

20. Sinfield A. Literature, Politics and Culture in Postwar Britain. London and Atlantic Highlands. Athlone Press, 1997. P. 436.

21. Tew Ph. The Contemporary British Novel. Continuum. 2004. P. 272. 
DOI: $10.15643 /$ libartrus-2015.1.3

\title{
Британский социальный роман конца XX века
}

\author{
(C) В. Г. Новикова \\ Нижегородский государственный университет \\ Россия, 603950 г. Нижний Новгород, проспект Гагарина, 23.
}

Email: wnovikova@mail.ru

Целью этой статьи является раскрытие особенностей нового содержания жанра британского социального романа, традиция которого сложилась в эпоху Нового времени и трансформировалась под влиянием радикальных перемен в самом типе мышления в период постмодерна. Постмодернистское мышление основано на представлении о мире как совокупности множащихся реальностей. Социальная действительность стала восприниматься как конструкция, в которой исчезают «усложненные интеллектом» ценности, в то время как элементарные конструкции повседневности умножаются. Эпистемологическая неуверенность также повлияла на жанровые изменения. В условиях «торгующей реальности» интеллектуалы теряют свои позиции, традиционные ценности разрушаются, знание гуманитарных наук исчезает, поскольку не имеет никакой рыночной стоимости, мечта о социальном равенстве исчезает вместе с идеей социализма. Дискурс собственности не может быть объединен с дискурсом морали. Новые позиции получают представители различных субкультур, которые становятся центром аморфной массовой культуры. Современный британский социальный роман представляет социальные изменения, которые произошли вследствие изменений типа мышления, фиксирует отсутствие социально значимых ориентиров и, как следствие, импульса к социально существенным действиям, что и позволяет манипулировать массами. Отсутствие национальной идеи связано с болезненным поиском национальной идентичности, которая, как полагают, является центральной проблемой в современном литературном процессе.

Ключевые слова: британский социальный роман, тип мышления, тип реальности, множащиеся реальности.

Просьба ссылаться на эту работу как: Новикова В. Г. Британский социальный роман конца XX века // Российский гуманитарный журнал. 2015. Т. 4. №1. С. 16-21. 